\title{
Development and Characterization of Transgenic Sugarcane with Insect Resistance and Herbicide Tolerance
}

\author{
Wen Zhi Wang, Ben Peng Yang, Xiao Yan Feng, Zheng Ying Cao, Cui Lian Feng, \\ Jun Gang Wang, Guo Ru Xiong, Lin Bo Shen, Jun Zeng, Ting Ting Zhao and \\ Shu Zhen Zhang*
}

Institute of Tropical Bioscience and Biotechnology, Chinese Academy of Tropical Agricultural Sciences, Haikou, China

\section{OPEN ACCESS}

Edited by:

Junhua Peng,

Center for Life Sci\&Tech of China National Seed Group Co. Ltd., China

Reviewed by:

Yang Rongzhong,

Sugarcane Research Institute, GXAAS, China

Elena Corredoira,

Consejo Superior de Investigaciones

Científicas (CSIC), Spain

*Correspondence:

Shu Zhen Zhang w780601@163.com

Specialty section:

This article was submitted to

Plant Biotechnology,

a section of the journal

Frontiers in Plant Science

Received: 08 June 2017

Accepted: 22 August 2017 Published: 28 September 2017

Citation:

Wang WZ, Yang $B P$, Feng $X Y$, Cao $Z Y$, Feng $C L$, Wang JG, Xiong GR, Shen $L B$, Zeng J,

Zhao TT and Zhang SZ (2017) Development and Characterization of Transgenic Sugarcane with Insect Resistance and Herbicide Tolerance.

Front. Plant Sci. 8:1535.

doi: 10.3389/fpls.2017.01535
Genetically modified crops which had been commercial applied extensively majorly are the insect resistance and herbicide tolerance events. In this study, the Bt insecticidal gene Cry1 Ab, the glyphosate-tolerant gene EPSPS, and the selection marker gene PMI were combined into a single transferred DNA fragment and introduced into sugarcane by Agrobacterium-mediated transformation. Thirty-three resistant plantlets were obtained after selection using a PMI/mannose selection system. Thirty of these resistant plantlets were PCR positive for the three target genes. Southern blot assay revealed that the copy number of the integrated fragment in the transformed plantlets varied from 1 to 7. ELISA analysis showed that 23 of the 33 resistant plantlets expressed Cry $1 A b$ and EPSPS protein. Five single-copy and ELISA-positive transgenic lines were tested under laboratory and field conditions to determine their resistance to insects and herbicides, and also evaluated their agronomic characteristics and industrial traits. Results showed that larvae fed with fodder mixture containing stem tissues from single-copy transgenic lines were weak and small, moreover, pupation and eclosion were delayed significantly during voluntary feeding bioassays. None of transgenic sugarcane was destroyed by cane borer while more than $30 \%$ of wild type sugarcane was destroyed by cane borer. For herbicide resistance, the transgenic plantlets grew healthy even when treated with up to $0.5 \%$ roundup while wild type plantlets would die off when treated with $0.1 \%$ roundup. Thus demonstrate that these transgenic lines showed strong insect resistance and glyphosate tolerance under both laboratory and field conditions. But in the field most of the transgenic plants were shorter and more slender than non-transformed control plants. So they presented poor agronomic characteristics and industrial traits than non-transformed control plants. Thus, a considerable number of embryogenic calli should be infected to obtain transgenic lines with potential for commercial use.

Keywords: sugarcane molecular breeding, EPSPS gene, Cry1Ab gene, PMI/mannose selection, Agrobacteriummediated transformation

\section{INTRODUCTION}

Herbicide tolerance and insect resistance are important traits considered in genetic improvement of various crops (James, 2013). Herbicide-tolerant transgenic crops represent the majority of genetically modified plants cultivated worldwide. In 2010, about $83 \%$ of the 148 million ha land dedicated for genetically modified crops was planted with herbicide-tolerant species (James, 2010; Bonny, 2011). Introduction of insect-resistant genes, such as Bt genes, is an effective and economic strategy used to improve the resistance of various crops to insects (Dutton et al., 2003; Torres and Ruberson, 2006; Valderrama et al., 2007; Gatehouse, 2008; Srikanth et al., 2011; 
Karthikeyan et al., 2012). Currently, commercially grown GM crops contain genes related to insect resistance and herbicide tolerance, which are valuable traits in production of major crops, such as corn and cotton. Transgenic plants stacked with multiple genes are mostly obtained by cross-hybridization among different transgenic plants (Cao et al., 2002; Datta et al., 2002; Zhao et al., 2003) or re-transformation with different genes (Jobling et al., 2002; Rosati et al., 2003; Singla-Pareek et al., 2003; Qi et al., 2004). However, these methods for combining transgenes present several significant limitations. For example, cross-hybridization is time consuming and labor intensive, transgenic lines segregate again in subsequent generations (Halpin et al., 2001; Halpin, 2005). In this regard, scholars have developed a fast and cost effective method of introducing one single transferred DNA (T-DNA) containing multiple genes, with each gene possessing its own promoter and terminator (Slater et al., 1999; Bohmert et al., 2000, 2002). This method can be used to introduce different genes into a plant by inserting them at the same site of the genome through one transformation cycle. Nevertheless, linking multiple genes into one T-DNA exhibits limitations in terms of T-DNA size and uneven gene expression among different genes (Jones et al., 1987; Peach and Velten, 1991). Thus, this method must be further improved (Poirier et al., 2000; Ye et al., 2000; Goderis et al., 2002; Thomson et al., 2002).

Sugarcane (Saccharum officinarum L.) is an important sugar crop that is widely cultivated in the tropical and subtropical regions. It provides about $80 \%$ of the world sugar (Raza et al., 2010) and more than 92\% of sugar in China (Guo et al., 2013). Equally important is the sugarcane borer, Diatraea saccharalis (F.), which is one of the most important lepidopteran pests attacking sugarcane plants and causing more than $10 \%$ loss in sugarcane yield worldwide (Ricaud et al., 1989). At the other hand, for sugarcane is mostly planted at rainfed cropland so it usually suffered badly by weed infestation and induce yield lost too. There are a lot of reports that introduced $\mathrm{Bt}$ gene to sugarcane cultivar and successfully obtained insect resistant sugarcane transgenic lines (Gao et al., 2016). Also, some reports introduced PAT/bar gene to sugarcane cultivar and obtained transgenic lines which resistant to Basta (glufosinateammonium) (Falco et al., 2000). But by now, there is no report that introduced Bt gene and EPSPS gene together to sugarcane cultivar and try for commercial used.

In this study, our goal was to check the possibility of transformed CrylAb and EPSPS gene together to sugarcane commercial cultivar, and to obtain transgenic lines that resistant to cane borer and herbicide. So a plant expression vector containing a CrylAb gene, an EPSPS gene and a selection marker gene PMI was adopted and transformed to a sugarcane commercial cultivar by agro-bacterium media transformation method. Embryogenic calli of this sugarcane cultivar were used as explant material and infected by agro-bacterium containing the plant expression vector. Resistant plants were obtained after selection by different kinds of medium containing mannose. Molecular characterization of these resistant plants was conducted by PCR, Southern blot and analysis. And then single copy and ELISA positive transgenic lines were chose for $\mathrm{lab}$ and field testing to determine the cane borer and herbicide resistant ability. Agronomic and industrial traits in field of these single copy transgenic lines were evaluated too. It is anticipated that the findings of this study will allow molecular breeding of sugarcanes that are resistant to cane borers and herbicide. But poor agronomic traits of these transgenic lines induce the difficult of commercial use.

\section{MATERIALS AND METHODS}

\section{Binary Vectors and Agrobacterium Strain}

The expression vector harboring the CrylAb gene, EPSPS gene, and the selection marker gene PMI was constructed in our previous research and stored in our laboratory. The Cryl $\mathrm{Ab}$ gene and the EPSPS gene were promoted by the Ubi-1 promoter and terminated by the nopaline synthase terminator. The selection marker gene was promoted by the Act-1 promoter (Figure 1). The expression vector was mobilized into Agrobacterium EHA105 through freeze thawing with liquid nitrogen. The Agrobacterium strain was cultured on YEP (yeast extract, $10 \mathrm{~g} / \mathrm{L}$; peptone, $10 \mathrm{~g} / \mathrm{L} ; \mathrm{NaCl}, 5 \mathrm{~g} / \mathrm{L}$ ) medium containing appropriate antibiotics (spectinomycin, $100 \mathrm{mg} / \mathrm{L}$; streptomycin, $50 \mathrm{mg} / \mathrm{L}$; and rifampicin, $10 \mathrm{mg} / \mathrm{L}$ ).

\section{Explant Material and Callus Induction}

The tops of sugarcane tillers containing immature leaf whorl were excised from the plant of variety ROC22 and used as source material for embryogenic callus induction. Transverse sections of immature sugarcane leaf whorls were prepared using the method described by Bower and Birch (1992). Transverse sections of approximately $1 \mathrm{~mm}$ thickness were cut immediately above the meristem and placed on callus induction medium [Murashige and Skoog (MS) + $30 \mathrm{~g} / \mathrm{L}$ sucrose $+2 \mathrm{mg} / \mathrm{L}$ 2,4-D and $8 \mathrm{mg} / \mathrm{L}$ agar] (Murashige and Skoog, 1962). Callus cultures were maintained at $28^{\circ} \mathrm{C}$ in the dark and supplied with fresh medium every 2 weeks. After approximately 45 days of induction, faint yellow and hard calli were selected and fragmented prior to transformation.

\section{Transformation and Selection}

Calli for transformation were collected and weighed prior to infection and placed into an Erlenmeyer flask. The Agrobacterium cells cultured in YEP medium were collection with centrifugal machine and re-suspended by infection medium (1/5 strength MS medium $+30 \mathrm{~g} / \mathrm{L}$ sucrose $+30 \mathrm{~g} / \mathrm{L}$ glucose $+100 \mathrm{mM}$ acetosyringone) and diluted to the concentration about $0.5-1.0$ of $\mathrm{OD}_{600}$. The flask contained calli was added with liquid infection medium with Agrobacterium harboring the expression vector and shaken gently for about $30 \mathrm{~min}$ in the dark. The Agrobacterium suspension was pumped out. The calli were transferred to a Petri dish, blotted dry to remove excess Agrobacterium suspension by using filter paper, and air dried for about $30 \mathrm{~min}$ on the cleaning bench. The calli were transferred to a new Petri dish and incubated in the dark at $22^{\circ} \mathrm{C}$ for 3 days (Dong et al., 2014). The infected calli were transferred to resting medium (MS + $1.0 \mathrm{mg} / \mathrm{L}$ 2,4-D + $30 \mathrm{~g} / \mathrm{L}$ sucrose $+8 \mathrm{~g} / \mathrm{L}$ agar $+300 \mathrm{mg} / \mathrm{L}$ timentin) and cultured in the dark at $28^{\circ} \mathrm{C}$ for 7 days. All infected 


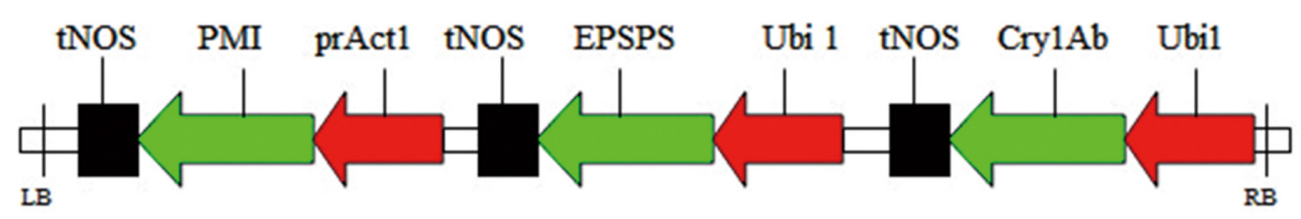

FIGURE 1 | Schematic of the T-DNA vector used for sugarcane transformation. PMI gene promoted by the prAct-1 promoter and the Cry 1 Ab gene and the EPSPS gene were promoted by the prUbi-1 promoter. prUbi-1, maize Ubi-1 promoter; prAct-1, rice Act-1 promoter; tNOS, nopaline synthase terminator.

calli were subsequently transferred to selection medium (MS + $2.0 \mathrm{mg} / \mathrm{L} \mathrm{2,4-D}+8 \mathrm{~g} / \mathrm{L}$ agar $+300 \mathrm{mg} / \mathrm{L}$ timentin $+5 \mathrm{~g}$ sucrose $+8 \mathrm{~g}$ mannose) and incubated in the dark at $28^{\circ} \mathrm{C}$ for 35 days. The resistant calli on the dark selection medium were transferred to regeneration medium $(\mathrm{MS}+1.0 \mathrm{mg} / \mathrm{L} 6-\mathrm{BA}+8 \mathrm{~g} / \mathrm{L}$ agar + $300 \mathrm{mg} / \mathrm{L}$ timentin $+5 \mathrm{~g}$ sucrose $+8 \mathrm{~g}$ mannose) and cultivated in an illuminated incubator for 14 days. After regeneration, green buds were transferred to elongation medium (MS $+8 \mathrm{~g} / \mathrm{L}$ agar + $300 \mathrm{mg} / \mathrm{L}$ timentin $+5 \mathrm{~g}$ sucrose $+8 \mathrm{~g}$ mannose) and cultivated in an illuminated incubator for 20 days. A single shoot from each of the buds was transferred to fresh elongation medium and cultured for 20 days. Resistant shoots were sampled for molecular analysis and transferred to soil.

\section{PCR Assay of Resistant Shoots}

Total genomic DNA was extracted from the leaves of the resistant shoots by using CTAB method. The vector plasmid was used as positive control, and total genomic DNA extracted from wild-type plants was used as negative control. The concentration of all DNA samples was measured using UV absorption method. DNA purity was analyzed using A260/A280 ratio. Based on the sequences of the CrylAb, EPSPS, and PMI genes, three pairs of primers were designed by Primer Premier version 5 for PCR assay (Table 1). Each $25 \mu \mathrm{L}$ of the reaction volume contained $2.5 \mu \mathrm{L}$ of PCR buffer $(10 \times), 2.0 \mu \mathrm{L}$ of dNTP mix, $1.0 \mu \mathrm{L}$ of $(100 \mathrm{ng} / \mathrm{L})$ template DNA, 1.0 $\mu \mathrm{L}$ of each forward and reverse primer, 0.2 U Taq DNA polymerase (Takara, Dalian, China), and $17.3 \mu \mathrm{L}$ of double-distilled $\mathrm{H}_{2} \mathrm{O}\left(\mathrm{ddH}_{2} \mathrm{O}\right)$. The PCR reaction was conducted as follows: initial polymerase activation at $98^{\circ} \mathrm{C}$ for $5 \mathrm{~min} ; 35$ cycles of $95^{\circ} \mathrm{C}$ for $30 \mathrm{~s}, 58^{\circ} \mathrm{C}$ for $30 \mathrm{~s}$, and $72^{\circ} \mathrm{C}$ for $30 \mathrm{~s}$; and final extension at $72^{\circ} \mathrm{C}$ for $10 \mathrm{~min}$. The PCR products were detected on $1.0 \%(\mathrm{w} / \mathrm{v})$ agarose gel. PCR analysis of all samples was repeated a

TABLE 1 | Primer sequences for PCR analysis.

\begin{tabular}{lccc}
\hline Gene & $\begin{array}{c}\text { Size of PCR } \\
\text { production }\end{array}$ & Primers \\
\hline PMl & $513 \mathrm{bp}$ & $\begin{array}{l}\text { Forward } \\
\text { Reverse }\end{array}$ & ACTACAAGGACCCCAACCAC \\
EPSPS & $643 \mathrm{bp}$ & Forward & CGCGATCACACCGAGAAGAT \\
& & Reverse & CCCATCACGAGGAACGACAT \\
Cry1Ab & $359 \mathrm{bp}$ & Forward & GTCACCTTCCCCCTGTACG \\
& & Reverse & TAGGTGCACGGATGATGCTC
\end{tabular}

All primers for PCR analysis were designed with Primer Premier version 5.0 with the amplified 513-bp DNA fragment for the PMI gene, 643-bp DNA fragment for the EPSPS gene, and 359-bp DNA fragment for the Cry1Ab gene. least three times to avoid appearance of false positive. Final results were then recorded in the table.

\section{Southern Blot Analysis}

Southern blot analysis was conducted to determine the integration and copy number of the integrated fragments. Approximately $10 \mu \mathrm{g}$ of total genomic DNA extracted from the transformed sugarcane plants was digested with EcoRI restriction enzyme, separated by electrophoresis agarose gel, and transferred onto Hybond N+ membrane. A 513-bp digoxin-labeled DNA fragment corresponding to the Cryl Ab gene was used as probe for hybridization according to the instruction manual (DIG High Prime DNA Labeling and Detection Starter Kit I, Roche).

\section{Detection of Cry1Ab and EPSPS Protein by ELISA}

All resistant plants were sampled and tested by ELISA. The sample from non-transgenic sugarcane stem was designated as negative control. Briefly, $0.1 \mathrm{~g}$ of stem tissues obtained from all samples were cut into small pieces and pushed to the bottom of a $1.5 \mathrm{~mL}$ Eppendorf tube. Pestles were inserted into each tube, and the stem tissue samples were ground by rotating the pestles against the sides of the tube with twisting motions. This process was continued until the stem tissue samples were well ground. The samples were then added with $1 \mathrm{~mL}$ of $1 \times$ phosphate-buffered saline with Tween 20 (PBST) buffer. The grinding step was repeated to mix the tissue thoroughly with $1 \times$ PBST extraction buffer. All tubes with the sample mixture were centrifuged for $1 \mathrm{~min}$, and the liquid supernatant was used for ELISA. ELISA testing was conducted using the ELISA Kit (Bt-Cry1Ab/1Ac ELISA Kit, Agdia, United States; CP4-EPSPS ELISA Kit, Agdia, United States) according to the manufacturer's instructions. The development of blue color in the ELISA mixture indicates positive protein expression. ELISA analysis for all samples was repeated at least three times to avoid appearance of false positive. Final results were then recorded in the table.

\section{Toxicity Testing of Single-Copy Transgenic Lines}

Helicoverpa armigera larvae were used to test the toxicity of Cry $1 \mathrm{Ab}$ protein expression in single-copy transgenic sugarcane stems through volunteer feeding bioassay. All third-instar larvae were starved for $12 \mathrm{~h}$ before feeding bioassay was initiated. Briefly, $4 \mathrm{~g}$ of fresh sugarcane stem tissue from single-copy transgenic lines was ground into powder with liquid nitrogen and mixed with $40 \mathrm{~mL}$ of larva fodder $(8 \mathrm{~g}$ 

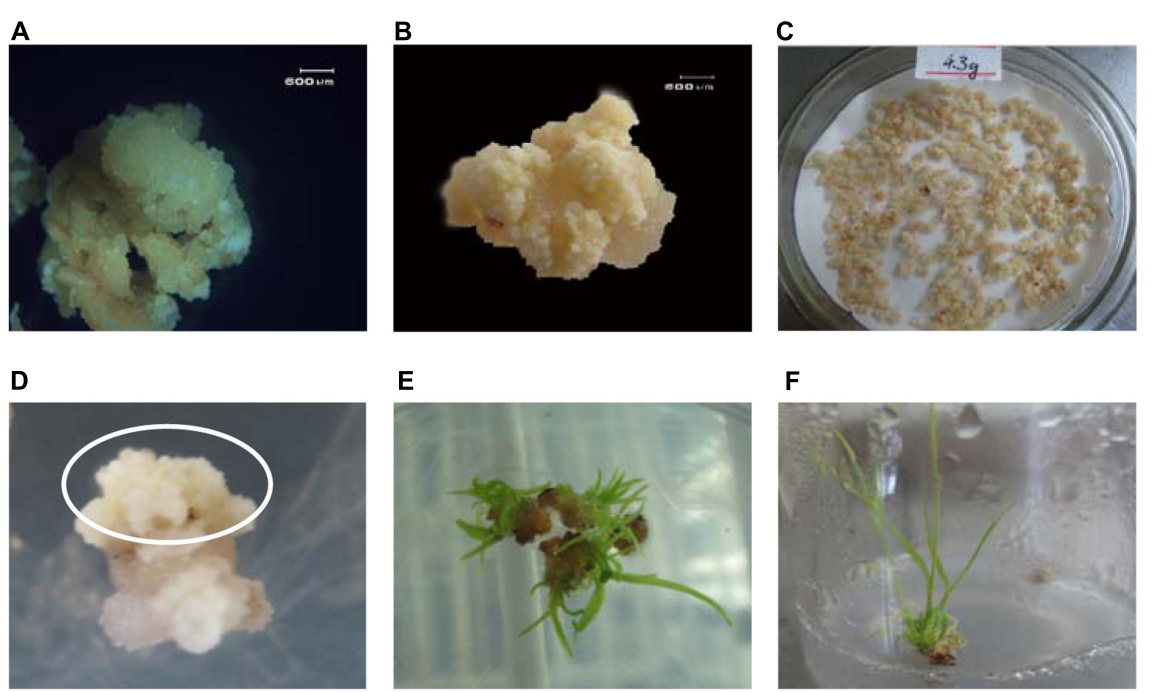

FIGURE 2 | Embryogenic callus induction and transformation. (A) Calli induced after 15 days; (B): Embryogenic calli formed after 45 days; (C): Embryogenic calli selected, fragmented, weighed, and air dried prior to transformation; (D) After 30 days of dark selection, several healthy resistant calli grew on the selection medium (E) After 14 days of regeneration, healthy cultivation-resistant calli emerged rapidly; (F) After 20 days of elongation, cultivation-resistant, dark-green shoots grew quickly.

of larva fodder powder $+40 \mathrm{~mL}$ of $\mathrm{ddH}_{2} \mathrm{O}+0.35 \mathrm{~g}$ of agar). The larva fodder mixture was equally distributed into 12-well cell culture plate (Cell Culture Plate, 12-well, Eppendorf, Germany). Twelve larvae with similar body size and weight were obtained from each well. The culture plates were covered and placed in an incubator $\left(28 \pm 2{ }^{\circ} \mathrm{C}, 70 \% \mathrm{RH}\right)$ in the dark.
All bioassays were conducted for 1 month. The body weight of each larva was recorded from the first to the eighth day. Average weight and the standard deviation of 12 larvae fed by different larva fodder were analyzed by Excel version 2007 . Development and pupation of larvae were also observed for about 1 month.

TABLE 2 | PCR, Southern blot, and ELISA analyses.

\begin{tabular}{|c|c|c|c|c|c|c|c|c|c|c|c|c|}
\hline \multicolumn{2}{|c|}{ Resistant shoots } & $\begin{array}{l}\text { T1 } \\
+\end{array}$ & $\begin{array}{l}\text { T2 } \\
+\end{array}$ & $\begin{array}{l}\text { T3 } \\
+\end{array}$ & $\begin{array}{l}\text { T4 } \\
+\end{array}$ & $\begin{array}{l}\text { T5 } \\
+\end{array}$ & $\begin{array}{l}\text { T6 } \\
+\end{array}$ & $\begin{array}{l}\text { T7 } \\
+\end{array}$ & $\begin{array}{c}\text { T8 } \\
+\end{array}$ & $\begin{array}{l}\text { T9 } \\
+\end{array}$ & $\begin{array}{c}\text { T10 } \\
+\end{array}$ & $\frac{\text { T11 }}{+}$ \\
\hline & EPSPS & + & + & + & + & + & + & + & + & + & + & + \\
\hline \multirow[t]{2}{*}{ ELISA } & EPSPS & + & + & + & + & + & + & - & + & + & + & + \\
\hline & Cry1Ab & + & + & + & + & + & + & - & + & + & - & + \\
\hline Copy No. & Cry1Ab & 2 & 5 & 1 & 6 & 1 & 3 & 2 & 7 & 1 & 3 & 4 \\
\hline \multirow[t]{3}{*}{ PCR } & PMl & + & + & + & + & + & + & + & + & + & - & + \\
\hline & EPSPS & + & + & + & + & + & + & + & + & + & - & + \\
\hline & Cry1Ab & + & + & - & + & + & + & + & + & + & - & + \\
\hline \multirow[t]{2}{*}{ ELISA } & EPSPS & + & - & - & + & - & - & + & + & + & - & + \\
\hline & Cry1Ab & - & - & - & + & - & - & + & + & + & - & + \\
\hline \multirow[t]{3}{*}{ PCR } & PMl & + & + & + & + & + & + & + & + & + & + & + \\
\hline & EPSPS & + & + & + & + & + & + & + & + & + & + & + \\
\hline & Cry1Ab & + & + & + & - & + & + & + & + & + & + & + \\
\hline \multirow[t]{2}{*}{ ELISA } & EPSPS & + & + & + & - & + & + & - & + & + & + & + \\
\hline & Cry1Ab & + & + & + & - & + & + & - & + & + & + & + \\
\hline Copy NO. & Cry1Ab & 4 & 5 & 7 & 0 & 2 & 4 & 3 & 2 & 5 & 6 & 3 \\
\hline
\end{tabular}

"+" PCR or ELISA analysis positive; "-" PCR or ELISA analysis negative. 


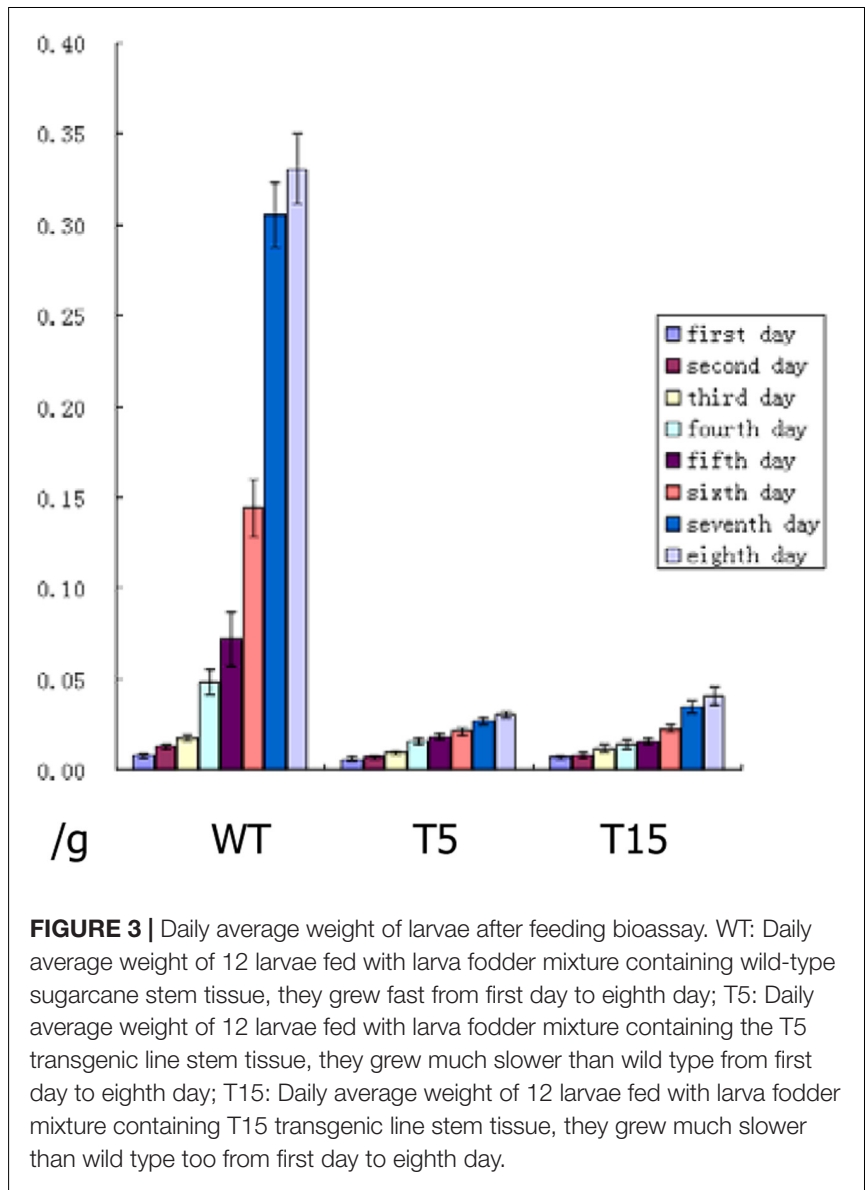

\section{Glyphosate Tolerance Testing of Single-Copy Transgenic Lines}

The propagated clones of each single-copy transgenic lines were grown in flowerpots and cultured for approximately 2 months until reaching a height of about $40 \mathrm{~cm}$. Subsequently, $25 \mathrm{~mL}$ of different dilutions (from 0.1 to $0.5 \%$ ) of Roundup (Monsanto, St. Louis, MO, United States) were sprayed to each plantlet of the clonal propagation of each transgenic line. Each treatment had three replications. After 10 days, the plantlets were observed, and pictures were taken.

\section{Evaluation of Agronomic and Industrial Traits in Single-Copy Transgenic Lines}

In isolated field trials, single-copy transgenic lines and nontransgenic controls were evaluated from 2014 to 2015 by using a randomized complete block design with 10 replications. Each block possessed one row of $10 \mathrm{~m}$ length, with $1.2 \mathrm{~m}$ space between rows, covering an area of $12 \mathrm{~m}^{2}$. During harvest in January 2015, yield estimates were obtained from the stems of each row. Height, stem diameter, and brix were measured in 10 consecutive principal stalks from 10 plants. The number of millable stalks in each row was also counted. Theoretical cane yield per hectare was calculated based on the area, number, and weight of stalks using equations:

$$
\begin{aligned}
\text { Weight of single stalk }(\mathrm{kg})= & 1 / 4 \times \pi \times(\text { diameter })^{2} \times \\
& \text { Height } \times 1.0 / 1000
\end{aligned}
$$

Number of stalks per hectare $=10000 \times$ Stalk number

$$
\text { per row / } 12
$$

Theoretical cane yield $(\mathrm{t} / \mathrm{ha})=$ Weight of single stalk $\times$

$$
\text { Number of stalks per hectare / } 1000 \text {. }
$$

Theoretical sucrose yield was calculated based on the average sucrose content and cane yield using equations:

$$
\text { Sucrose content }(\%)=\text { brix } \times 1.0825-7.703 \text {; }
$$

and

Sucrose yield $(\mathrm{t} / \mathrm{ha})=$ Cane yield $(\mathrm{t} / \mathrm{ha}) \times$ Sucrose content $(\%)$

In the field trials, the percentage of stalks damaged by the sugarcane borer and agronomic traits were recorded. Roundup tolerance in the field was checked by determining the spray concentration of roundup $(0.2 \%)$.

\section{RESULTS}

\section{Plant Material and Callus Induction}

ROC22 represents the largest acreage of sugarcane cultivars in China; Scholars have focused on improving the resistance of this cultivar to herbicides and insect borers.

In this research, 4 tops of sugarcane tillers containing immature leaf whorl were excised from the plantlets of variety ROC22 and used as source material for embryogenic callus induction. Calli grew fast and healthy after 15 days of induction, but the embryogenic calli had not formed (Figure 2A). Improved embryogenic calli formed after renewed twice of induction medium as described in material and methods (Figure 2B). $4.3 \mathrm{~g}$ of faint yellow and hard calli were obtained and fragmented before transformation (Figure 2C).

\section{Transformation and Selection}

After 30 min of infection, 3 days of co-cultivation, 7 days of resting cultivation, and approximately 35 days of dark selection, about $5 \%$ of infected callus grew out new resistant embryogenic calli (around $5 \mathrm{~mm}$ in size) on the selection medium (Figure 2D). These resistant embryogenic calli were obtained from the dark selection medium and transferred to the regeneration medium. The somatic embryos soon formed on the resistant embryogenic calli in 7 days. And then monocotyledon formed and finally germinated in follow 7-14 days (Figure 2E). Finally, 33 independent resistant shoots (Figure 2F) were obtained after elongation selection. The shoots were sampled for PCR analysis. 

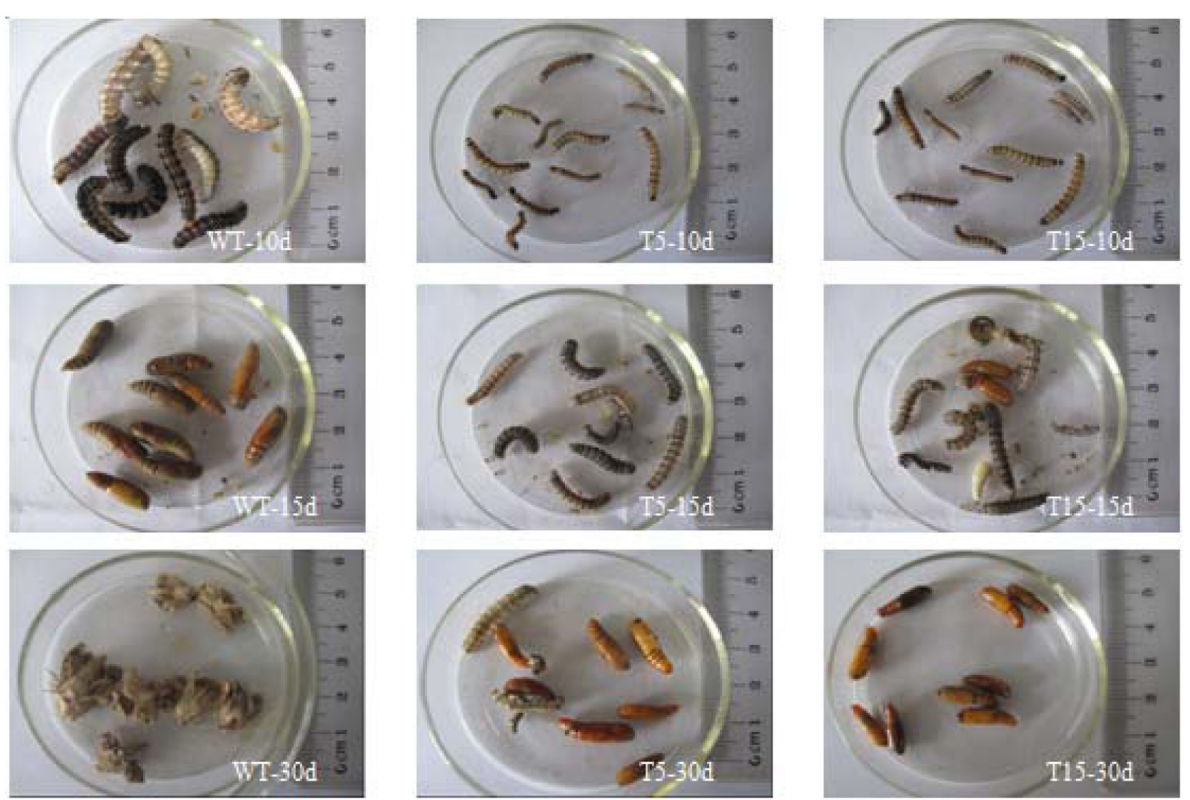

FIGURE 4 | Pupation and eclosion of larvae during feeding bioassay. WT-10d: 10 days after larvae fed by wild type stem tissue; WT-15d: 15 days after larvae fed by wild type stem tissue; WT-30d: 30 days after larvae fed by wild type stem tissue; The left three images shows that larvae feed by wild type stem tissue grow healthy and all larvae underwent eclosion in 30 days. T5-10d: 10 days after larvae fed by T5 stem tissue; T5-15d: 15 days after larvae fed by T5 stem tissue; T5-30d:

30 days after larvae fed by $T 5$ stem tissue. The middle three images shows that larvae feed by T5 stem tissue grew slowly and small, the pupation and eclosion was delayed badly. T15-10d: 10 days after larvae fed by T15 stem tissue; T15-15d: 15 days after larvae fed by T15 stem tissue; T15-30d: 30 days after larvae fed by T15 stem tissue. The right three images shows that larvae feed by T5 stem tissue grew slowly and small, the pupation and eclosion was delayed badly.

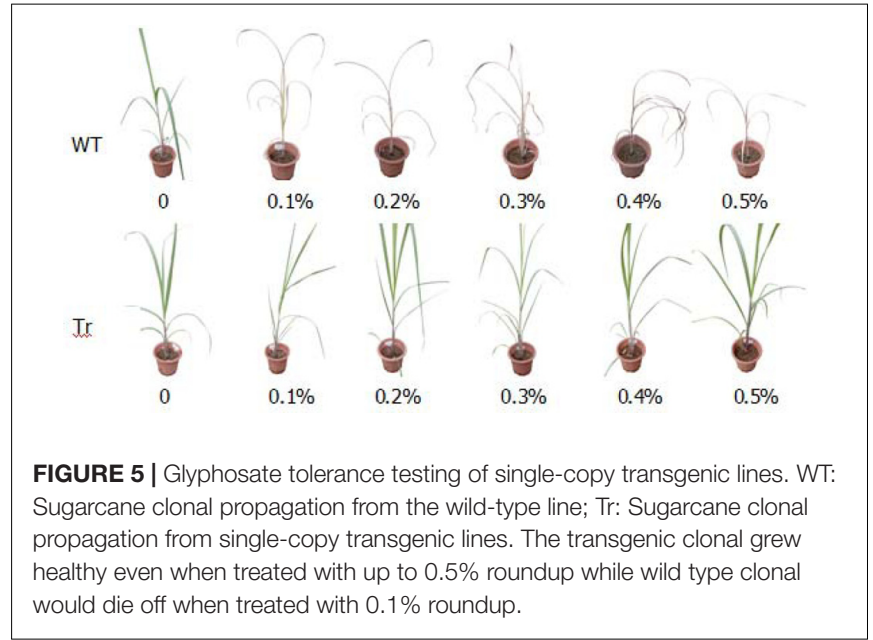

\section{PCR and Southern Blot Analyses of Potential Transformed Shoots}

A total of 33 resistant shoots were sampled and evaluated for PMI gene, EPSPS gene, and Cry1Ab gene integration by PCR after elongation cultivation. Thirty-two of the shoots were PCR positive for PMI and EPSPS genes, whereas 30 of the shoots were PCR positive for the Cryl Ab gene. A total of 30 transgenic lines were PCR positive for all of the three target genes (Table 2). Southern blot analysis was performed for the 33 resistant shoots by using probes specific to the CrylAb gene to determine the copy number of the inserted T-DNA. The copy number of the integrated fragment in the transformed lines varied from 1 to 7 (Table 2), and transgenic lines T3, T5, T9, T15, and T18 were confirmed to be single-copy inserted events.

\section{ELISA Analysis of EPSPS and Cry1Ab Protein}

Double-antibody sandwich ELISA was performed to determine the protein expression levels of EPSPS and Cry1Ab in the stem tissues of all 33 resistant shoots. The development of blue color in the ELISA reaction mixtures indicates positive protein expression. 25 resistant shoots were positive for EPSPS protein expression, and 23 resistant shoots were positive for Cry1 Ab protein expression. A total of 23 resistant shoots were positive for both EPSPS and CrylAb protein expression (Table 2).

\section{Toxicity Testing of Single-Copy Transgenic Lines}

Five single-copy transgenic lines, namely, T3, T5, T9, T15, and T18, were selected to test the toxicity of the Cry1Ab protein expressed in stems. The body weight of each larva was recorded for the first 8 days. Larva pupation and eclosion were observed for 1 month of the bioassay treatment. Larvae fed with fodder mixture containing stem tissues from all single-copy transgenic lines were weak and small; moreover, pupation and eclosion were delayed significantly. T5 and T15 showed the optimal inhibition of larva growth. The average weight of 12 larvae fed with wildtype sugarcane stem tissue increased from 0.0079 to $0.3308 \mathrm{~g}$ 
TABLE 3 | Agronomic characteristics, industrial traits, and the stalk borer damage percentage in single-copy transgenic lines and the control lines.

\begin{tabular}{|c|c|c|c|c|c|c|c|}
\hline Tr Lines & Height (cm) & Diameter (cm) & Brix (\%) & SNR & TCY (t/ha) & TSY (t/ha) & SDR (\%) \\
\hline T3 & $286.10 \pm 16.06 c$ & $2.65 \pm 0.17 a b$ & $20.75 \pm 1.09 a b$ & $111.90 \pm 4.84 a b$ & $132.48 \pm 5.73 d$ & $17.98 \pm 0.74 d$ & 0 \\
\hline T5 & $285.20 \pm 10.66 c$ & $2.49 \pm 0.19 b$ & $20.5 \pm 1.25 a b$ & $108.80 \pm 3.58 b$ & $112.48 \pm 3.71 \mathrm{e}$ & $14.97 \pm 0.47 e$ & 0 \\
\hline T9 & $331.9 \pm 15.76 a b$ & $2.61 \pm 0.15 b$ & $20.95 \pm 1.12 \mathrm{a}$ & $108.80 \pm 3.43 b$ & $146.95 \pm 4.6 c$ & $20.24 \pm 0.6 c$ & 0 \\
\hline $\mathrm{T} 15$ & $343.90 \pm 26.58 a$ & $2.66 \pm 0.21 \mathrm{ab}$ & $20.9 \pm 0.84 a b$ & $113.10 \pm 6.42 \mathrm{ab}$ & $164.08 \pm 9.3 b$ & $22.51 \pm 1.21 b$ & 0 \\
\hline T18 & $278.90 \pm 17.15 c$ & $2.53 \pm 0.294 b$ & $20.00 \pm 1.08 b$ & $113.10 \pm 5.24 a b$ & $117.87 \pm 5.46 \mathrm{e}$ & $15.09 \pm 0.66 e$ & 0 \\
\hline CK & $356.80 \pm 8.87 a$ & $2.84 \pm 0.18 a$ & $20.95 \pm 0.72 a$ & $114.70 \pm 5.38 a$ & $197.96 \pm 9.28 a$ & $27.26 \pm 1.21 \mathrm{a}$ & $31 \%$ \\
\hline
\end{tabular}

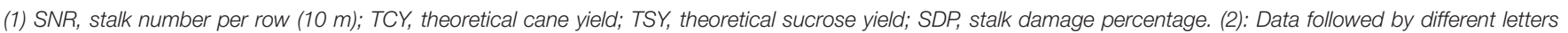
indicate significant difference at 0.05 level (LSD test).

in the first 8 days. Meanwhile larvae fed with T5 and T15 stem tissues grew from 0.0069 to $0.0306 \mathrm{~g}$ and from 0.0072 to $0.0405 \mathrm{~g}$, respectively (Figure 3).

At 10 days after feeding bioassay, larvae fed with wild-type stem tissue were strong and fat, whereas larvae fed with T5 and T15 were weak and slender. At 15 days after feeding bioassay, all larvae fed with wild-type stem tissue had pupated, whereas larvae fed with T5 and T15 started to pupate. At 30 days after feeding bioassay, all larvae fed with wild-type stem tissue underwent eclosion, whereas larvae fed with T5 and T15 were in the progress of pupation (Figure 4).

\section{Glyphosate Tolerance Testing of Single-Copy Transgenic Lines}

Ten days after spraying different dilutions of roundup (from 0.1 to $0.5 \%$ ), all wild-type sugarcane plantlets died even those given with the lowest roundup concentration of $0.1 \%$. The transgenic plantlets grew healthy even when treated with up to $0.5 \%$ roundup (Figure 5 ). Hence, the transgenic lines possess high glyphosate tolerance.

\section{Evaluation of Agronomic and Industrial Traits in Single-Copy Transgenic Lines}

The agronomic and industrial traits of the five single-copy transgenic lines and control sugarcane cultivar ROC22 were
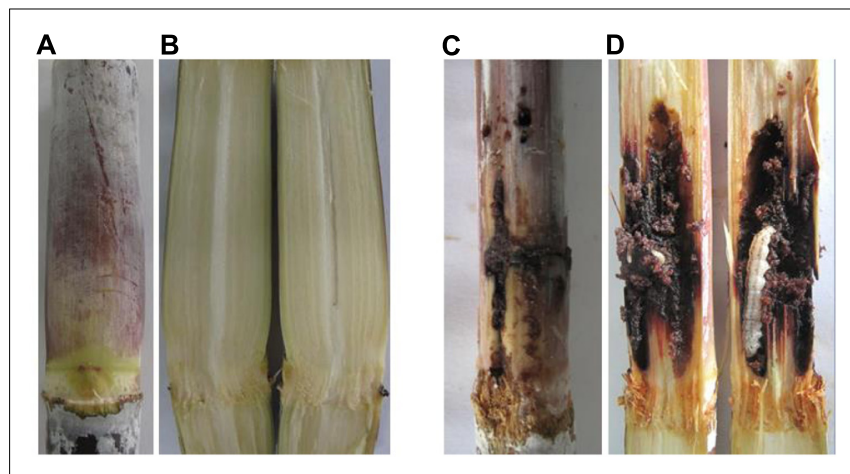

FIGURE 6 | Comparison of cane borer damage between transgenic and control line stalks. (A) Stem symptom of transgenic lines (grew healthy and did not destroy by cane borer); (B) Stem symptom of transgenic lines (inside stalk); (C) Stem symptom of control lines (Destroyed badly by cane borer); (D) Stem symptom of control lines (inside stalk grew with cane borer). investigated in mature stage plants. As shown in Table 3, univariate statistical analysis indicated that stalk height was low in T9 and T15 but was not significantly different from the control. By contrast, the stalk heights of the three other transgenic lines were significantly lower than that of the control. The stalk diameter of T3 and T18 was smaller but not significantly different from that of the control, whereas the three other transgenic lines presented significantly smaller diameter than the control. In terms of brix, only T18 presented significantly lower values compared with the control, whereas the other lines presented lower but not significantly different values compared with the control. The millable stalk number of each row of T5 and T9 was significantly lower than that of the control, whereas the three other lines showed similar numbers to that of the control. Finally, theoretical cane yield and sucrose yield were calculated based height, diameter, brix, and number of millable stalks in a row. The yield of the five transgenic lines was significantly lower than that of the control.

In the field trials, none of stalks from the transgenic lines showed cane borer damage, whereas $31 \%$ of stalks from the control lines were damaged by cane borer (Figure 6 and Table 3). As observed for the Roundup tolerance testing in the field trials, at 10 days after spraying of $0.2 \%$ Roundup, control sugarcane lines died off, whereas the transgenic lines remained dark green and grew healthy (Figure 7).

\section{DISCUSSION}

Transgenic crops with more than one trait offer broad agronomic enhancements to meet requirements under complex farming conditions. Herbicide tolerance and insect resistance are important traits considered in genetic improvement of various crops. For sugarcane, yield lost were caused by pests attacking and weed infestation too. So herbicide tolerance and insect resistance are the two important characters in genetic improvement of sugarcane. But by now, there is no report that introduced $\mathrm{Bt}$ gene and EPSPS gene together to sugarcane cultivar and try for commercial used.

In this research, we constructed the plant expression vector containing three expression cassettes, Ubi1-CrylAb-tNOS, Ubi1EPSPS-tNOS and prAct1-PMI-tNOS. The two target genes were placed under the control of the constitutively expressed promoter Ubil and the selectable marker gene PMI was placed under the control of the promoter Act1. Maize Ubi-1 promoter is a 

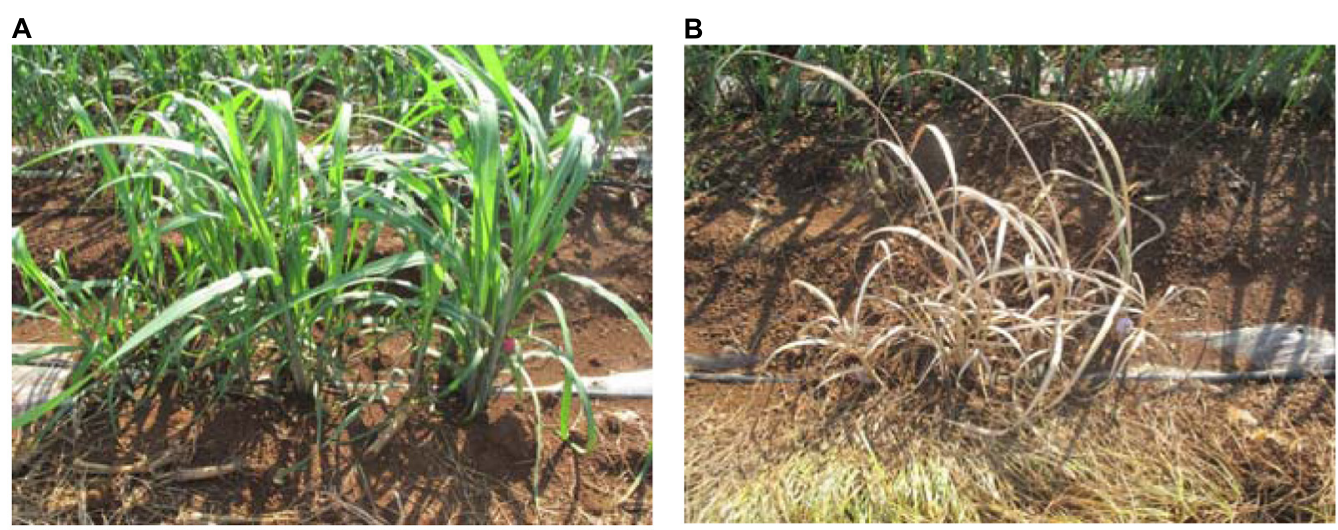

FIGURE 7 | Roundup tolerance testing in field trials. (A) Transgenic lines grew healthy 10 days after sprayed by $0.2 \%$ Roundup; (B) Control lines totally died off 10 days after sprayed by $0.2 \%$ Roundup.

constitutive and strong promoter and had been commonly used in previous sugarcane genetic improvement researches (Falco and Silva, 2003; Zhangsun et al., 2007). So we adopted this promoter to make sure that the two target genes would express successfully in transgenic lines. Finally the ELISA results demonstrated that the Ubil promoter works well in transgenic lines as anticipated.

ROC22 is an important commercial sugarcane cultivar in China and a lot of genetic improvement project had been done to it. So in this research embryogenic calli was induced from this cultivar and used for transformation. Agro-bacterium infection and resistant calli selection process was conducted in accordance to the protocol induced from Syngenta Biotechnology Inc. PMI/Mannose selection system of transgenic sugarcane was firstly established by this company and works very well (Dong et al., 2014). A total of $4.3 \mathrm{~g}$ embryogenic calli was collected and infected, and then 33 resistant plantlets were obtained and sampled for PCR detection. Thirty-two of the plantlets were PCR positive for PMI and EPSPS genes, whereas 30 of the shoots were PCR positive for the CrylAb gene (Figure 4). A total of 30 transgenic lines were PCR positive for all of the three exogenous genes (Table 2). Plantlet number of PCR positive of three exogenous genes are different, this means that in some transgenic lines part of T-DNA fragment may fractured and missed during the integration process. This usually happen during the transformation by insertion a single and long T-DNA fragment containing multiple genes (Cao et al., 2005).

Though 30 shoots were PCR positive for both EPSPS gene and CrylAb gene, but ELISA analysis showed that only 23 shoots expressed Cry1 Ab and EPSPS protein. This means that EPSPS gene and Cry $1 \mathrm{Ab}$ gene of the other 7 shoots had been silenced. Exogenous gene silence is normal in the transgenic plants, this had been discovered at least 20 years ago (Stam et al., 1997). And in this research about $23 \%$ of sugarcane transgenic lines were silenced for two target genes.

After molecular characterization five single copy and ELISA positive transgenic lines were chose for further research. In voluntary feeding bioassay, the growth and development of larvae that fed on stem tissue from transgenic lines were significantly retarded as compared with those of larvae that fed on stem tissue from non-transgenic lines. At the end all the larvae fed on stem tissue from transgenic lines were survived and successfully pupated. In this testing, if more than $4 \mathrm{~g}$ of stem tissue from transgenic lines was added to larva fodder medium, the result may different. Some larvae may die off and can't successfully pupate finally.

Glyphosate tolerance ability was tested by the spray different dilution of Roundup (from 0.1 to $0.5 \%$ ). All wild-type sugarcane plantlets died even at the lowest Roundup concentration of $0.1 \%$, whereas the transgenic plantlets grew healthily even at a Roundup concentration reaching $0.5 \%$. Higher concentration of Roundup had not been tested, because $0.1-0.2 \%$ is the realistic concentration that used in field.

In the field trials, the five single copy transgenic lines exhibited excellent cane borer resistance and herbicide tolerance but poor agronomic traits; in particular, the transgenic plants were shorter and more slender than the non-transformed control plants. None of the lines can be selected for commercial use. As the biggest biotechnology company in the world such as Syngenta and Monsanto, they usually product hundreds of transgenic lines for one vector, and at the end one or two were chose and tried for commercial used. Therefore, a considerable number of embryogenic calli should be infected to produce transgenic lines with potential for commercial use.

The present study revealed that it is possible to transform CrylAb gene and EPSPS gene together to sugarcane cultivar and obtain transgenic sugarcane lines that exhibit excellent cane borer resistance and herbicide tolerance. But considerable number of embryogenic calli should be infected to produce transgenic lines with potential for commercial use.

\section{AUTHOR CONTRIBUTIONS}

WW took charge of genetic transformation and paper writing. $\mathrm{BY}$ and $\mathrm{SZ}$ are the directors of the original research and paper writing. XF and CF took charge of insect bioassay and herbicide resistant testing of transgenic lines. JW took charge of vector 
construction and molecular analysis of transformed plants. ZC and TZ took charge of original paper revising. GX and JZ took charge of field investigation of transgenic plants. LS took charge of data analysis and picture making.

\section{REFERENCES}

Bohmert, K., Balbo, I., Kopka, J., Mittendorf, V., Nawrath, C., Poirier, Y., et al. (2000). Transgenic Arabidopsis plants can accumulate polyhydroxybutyrate to up to $4 \%$ of their fresh weight. Planta 211, 841-845. doi: 10.1007/ s004250000350

Bohmert, K., Balbo, I., Steinbuchel, A., Tischendorf, G., and Willmitzer, L. (2002). Constitutive expression of the beta-ketothiolase gene in transgenic plants. A major obstacle for obtaining polyhydroxybutyrate-producing plants. Plant Physiol. 128, 1282-1290. doi: 10.1104/pp.010615

Bonny, S. (2011). Herbicide-tolerant transgenic soybean over 15 years of cultivation: pesticide use, weed resistance, and some economic issues. The case of the USA. Sustainability 3, 1302-1322. doi: 10.3390/su3091302

Bower, R., and Birch, R. G. (1992). Transgenic sugarcane plants via microprojectile bombardment. Plant J. 2, 409-416. doi: 10.1111/j.1365-313X.1992.00409.x

Cao, J., Zhao, J. Z., and Tang, J. D. (2002). Broccoli plants with pyramided cry1Ac and cry $1 \mathrm{C}$ Bt genes control diamondback moths resistant to Cry $1 \mathrm{~A}$ and Cry $1 \mathrm{C}$ proteins. Theor. Appl. Genet. 105, 258-264. doi: 10.1007/s00122-002-0942-0

Cao, M. X., Huang, J. Q., Wei, Z. M., Yao, Q. H., Wan, C. Z., and Lu, J. A. (2005). Agrobacterium-mediated multiple gene transformation in rice using a single vector. J. Integr. Plant Biol. 47, 233-242. doi: 10.1111/j.1744-7909.2005.00015.x

Datta, K., Baisakh, N., Thet, K. M., Tu, J., and Datta, S. K. (2002). Pyramiding transgenes for multiple resistance in rice against bacterial blight, yellow stem borer and sheath blight. Theor. Appl. Genet. 106, 1-8. doi: 10.1007/s00122-0021014-1

Dong, S. J., Delucca, P., Geijskes, R. J., Ke, J., Mayo, K., Mai, P., et al. (2014). Advances in Agrobacterium-mediated sugarcane transformation and stable transgene expression. Sugar Tech 16, 366-371. doi: 10.1007/s12355-013-0294-x

Dutton, A., Romeis, J., and Bigler, F. (2003). Assessing the risks of insect resistant transgenic plants on entomophagous arthropods Bt-maize expressing Cryl $\mathrm{Ab}$ as a case study. Biocontrol 48, 611-636. doi: 10.1023/A:1026313719424

Falco, M. C., Neto, A. T., and Ulian, E. C. (2000). Transformation and expression of a gene for herbicide resistance in a Brazilian sugarcane. Plant Cell Rep. 19, 1188-1194. doi: 10.1007/s002990000253

Falco, M. C., and Silva, M. C. (2003). Expression of soybean proteinase inhibitors in transgenic sugarcane plants: effects on natural defense against Diatraea saccharalis. Plant Physiol. Biochem. 41, 761-766. doi: 10.1016/S0981-9428(03) 00100- 1

Gao, S., Yang, Y., Wang, C., Guo, J., Zhou, D., Wu, Q., et al. (2016). Transgenic sugarcane with a crylAc gene exhibited better phenotypic traits and enhanced resistance against sugarcane borer. PLOS ONE 11:e0153929. doi: 10.1371/ journal.pone.0153929

Gatehouse, J. A. (2008). Biotechnolegical prospects for engineering insect-resistant plants. Plant Physiol. 146, 881-887. doi: 10.1104/pp.107.111096

Goderis, I. J. W. M., De Bolle, M. F. C., Francois, I. E. J. A., Wouters, P. F. J., Broekaert, W. F., and Cammue, B. P. A. (2002). A set of modular plant transformation vectors allowing flexible insertion of up to six expression units. Plant Mol. Biol. 50, 17-27. doi: 10.1023/A:1016052416053

Guo, J. L., Xu, L. P., Su, Y. C., Wang, H. B., Gao, S. W., Xu, J. S., et al. (2013). ScMT2-1-3, a metallothionein gene of sugarcane, plays an important role in the regulation of heavy metal tolerance/accumulation. Biomed Res. Int. 2013:904769. doi: 10.1155/2013/904769

Halpin, C. (2005). Gene stacking in transgenic plants-the challenge for 21 st century plant biotechnology. Plant Biotechnol. J. 3, 141-155. doi: 10.1111/j. 1467-7652.2004.00113.x

Halpin, C., Barakate, A., Askari, B. M., Abbott, J. C., and Ryan, M. D. (2001). Enabling technologies for manipulating multiple genes on complex pathways. Plant Mol. Biol. 47, 295-310. doi: 10.1023/A:1010604120234

James, C. (2010). Global Status of Commercialized Biotech/GM Crops: 2010. ISAAA Brief No. 42. Ithaca, NY: International Service for the Acquisition of AgriBiotech Applications (ISAAA).

\section{FUNDING}

This work was funded by Ministry of Science and Technology of the People's Republic of China 863 Program (SS2013AA100604).

James, C. (2013). Global Status of Commercialized Biotech/GM Crops: 2013. ISAAA Brief No. 46. Ithaca, NY: International Service for the Acquisition of AgriBiotech Applications (ISAAA).

Jobling, S. A., Westcott, R. J., Tayal, A., Jeffcoat, R., and Schwall, G. P. (2002). Production of a freeze-thaw-stable potato starch by antisense inhibition of three starch synthase genes. Nat. Biotechnol. 20, 295-299. doi: 10.1038/ nbt0302-295

Jones, J. D. G., Gilbert, D. E., Grady, K. L., and Jorgensen, R. A. (1987). T-DNA structure and gene expression in petunia plants transformed by Agrobacterium tumefaciens c58 derivatives. Mol. Gen. Genet. 207, 478-485. doi: 10.1007/ BF00331618

Karthikeyan, A., Valarmathi, R., Nandini, S., and Nandhakumar, M. (2012). Genetically modified crops: insect resistance. Biotechnology 11, 119-126. doi: 10.3923/biotech.2012.119.126

Murashige, T., and Skoog, F. (1962). A revised medium for rapid growth and bioassays with tobacco tissue cultures. Plant Physiol. 15, 473-497. doi: 10.1111/ j.1399-3054.1962.tb08052.x

Peach, C., and Velten, J. (1991). Transgene expression variability (position effect) of CAT and GUS reporter genes driven by linked divergent T-DNA promoters. Plant Mol. Biol. 17, 49-60. doi: 10.1007/BF00036805

Poirier, Y., Ventre, G., and Nawrath, C. (2000). High-frequency linkage of coexpressing T-DNA in transgenic Arabidopsis thaliana transformed by vacuuminfiltration of Agrobacterium tumefaciens. Theor. Appl. Genet. 100, 487-493. doi: $10.1007 / \mathrm{s} 001220050063$

Qi, B., Fraser, T., Mugford, S., Dobson, G., Sayanova, O., Butler, J., et al. (2004). Production of very long chain polyunsaturated omega-3 and omega- 6 fatty acids in plants. Nat. Biotechnol. 22, 739-745. doi: 10.1038/nbt972

Raza, G., Ali, K., Mukhtar, Z., Mansoor, M., Arshad, M., and Asad, S. (2010). The response of sugarcane (Saccharum officinarum L.) genotypes to callus induction, regeneration and different concentrations of the selective agent (geneticin-418). Afr. J. Biotechnol. 9, 8739-8747.

Ricaud, C., Egan, B. T., Gillaspie, A. G., and Hughes, C. G. (1989). Diseases of Sugarcane: Major Diseases. Amsterdam: Elsevier Science Publishers B.V.

Rosati, C., Simoneau, P., Treutter, D., Poupard, P., Cadot, Y., Cadic, A., et al. (2003). Engineering of flower color in forsythia by expression of two independently-transformed dihydroflavonol 4-reductase and anthocyanidin synthase genes of the flavonoid pathway. Mol. Breed. 12, 197-208. doi: 10.1023/ A:1026364618719

Singla-Pareek, S. L., Reddy, M. K., and Sopory, S. K. (2003). Genetic engineering of the glyoxalase pathway in tobacco leads to enhanced salinity tolerance. Proc. Natl. Acad. Sci. U.S.A. 100, 14672-14677. doi: 10.1073/pnas.2034667100

Slater, S., Mitsky, T. A., Houmiel, K. L., Hao, M., Reiser, S. E., Taylor, N. B., et al. (1999). Metabolic engineering of Arabidopsis and Brassica for poly(3-hydroxybutyrate-co-3-hydroxyvalerate) copolymer production. Nat. Biotechnol. 17, 1011-1016. doi: 10.1038/13711

Srikanth, J., Subramonian, N., and Premachandran, M. (2011). Advances in transgenic research for insect resistance in sugarcane. Trop. Plant Biol. 4, 52-61. doi: 10.1007/s12042-011-9077-2

Stam, M., Mol, J. N. M., and Kooter, J. M. (1997). The silence of genes in transgenic plants. Ann. Bot. 79, 3-12. doi: 10.1006/anbo.1996.0295

Thomson, J. M., Lafayette, P. R., Schmidt, M. A., and Parrott, W. A. (2002). Artificial gene-clusters engineered into plants using a vector system based on intron- and intein-encoded endonucleases. In Vitro Cell. Dev. Biol. Plant 38, 537-542. doi: 10.1079/IVP2002329

Torres, J. B., and Ruberson, J. R. (2006). Spatial and temporal dynamics of oviposition behavior of bollworm and three of its predators in $\mathrm{Bt}$ and non-Bt cotton fields. Entomol. Exp. Appl. 120, 11-22. doi: 10.1111/j.1570-7458.2006. 00422.x

Valderrama, A. M., Velasquez, N., Rodriguez, E., Zapata, A., Zaidi, M. A., and Altosaar, I. (2007). Resistance to Tecia solanivora (Lepidoptera: Gelechiidae) in three transgenic Andean varieties of potato expressing Bacillus thuringiensis 
Cry1Ac protein. J. Econ. Entomol. 100, 172-179. doi: 10.1603/0022-0493(2007) 100[172:RTTSLG]2.0.CO;2

Ye, X. D., Al Babili, S., Kloti, A., Zhang, J., Lucca, P., Beyer, P., et al. (2000). Engineering the provitamin A (beta-carotene) biosynthetic pathway into (carotenoid-free) rice endosperm. Science 287, 303-305. doi: 10.1126/science. 287.5451.303

Zhangsun, D. T., Luo, S. L., Chen, R. K., and Tang, K. X. (2007). Improved agro-bacterium mediated genetic transformation of GNA transgenic sugarcane. Biologia 62, 386-393. doi: 10.2478/s11756-007-0096-2

Zhao, J. Z., Cao, J., and Li, Y. X. (2003). Transgenic plants expressing two Bacillus thuringiensis toxins delay insect resistance evolution. Nat. Biotechnol. 21, 1493-1497. doi: 10.1038/nbt907
Conflict of Interest Statement: The authors declare that the research was conducted in the absence of any commercial or financial relationships that could be construed as a potential conflict of interest.

Copyright () 2017 Wang, Yang, Feng, Cao, Feng, Wang, Xiong, Shen, Zeng, Zhao and Zhang. This is an open-access article distributed under the terms of the Creative Commons Attribution License (CC BY). The use, distribution or reproduction in other forums is permitted, provided the original author(s) or licensor are credited and that the original publication in this journal is cited, in accordance with accepted academic practice. No use, distribution or reproduction is permitted which does not comply with these terms. 